\title{
Recent advances in rhythm control for atrial fibrillation
}

\section{[version 1; peer review: 2 approved]}

\section{Richard Bond (D1), Brian Olshansky², Paulus Kirchhof1,3-6}

\author{
${ }^{1}$ University Hospitals Birmingham NHS Foundation Trust, Birmingham, UK \\ 2University of Iowa, Iowa City, USA \\ ${ }^{3}$ Department of Cardiovascular Medicine, Hospital of the University of Münster, Münster, Germany \\ ${ }^{4}$ Atrial Fibrillation NETwork (AFNET), Münster, Germany \\ 5Institute of Cardiovascular Sciences, University of Birmingham, Birmingham, UK \\ ${ }^{6}$ Sandwell and West Birmingham NHS Trust, Birmingham, UK
}

V1 First published: 03 Oct 2017, 6(F1000 Faculty Rev):1796
https://doi.org/10.12688/f1000research.11061.1

Latest published: 03 Oct 2017, 6(F1000 Faculty Rev):1796

https://doi.org/10.12688/f1000research.11061.1

\section{Abstract}

Atrial fibrillation (AF) remains a difficult management problem. The restoration and maintenance of sinus rhythm-rhythm control therapy-can markedly improve symptoms and haemodynamics for patients who have paroxysmal or persistent AF, but some patients fare well with rate control alone. Sinus rhythm can be achieved with anti-arrhythmic drugs or electrical cardioversion, but the maintenance of sinus rhythm without recurrence is more challenging. Catheter ablation of the AF triggers is more effective than anti-arrhythmic drugs at maintaining sinus rhythm. Whilst pulmonary vein isolation is an effective strategy, other ablation targets are being evaluated to improve sinus rhythm maintenance, especially in patients with chronic forms of AF. Previously extensive ablation strategies have been used for patients with persistent AF, but a recent trial has shown that pulmonary vein isolation without additional ablation lesions is associated with outcomes similar to those of more extensive ablation. This has led to an increase in catheter-based technology to achieve durable pulmonary vein isolation. Furthermore, a combination of antiarrhythmic drugs and catheter ablation seems useful to improve the effectiveness of rhythm control therapy. Two large ongoing trials evaluate whether a modern rhythm control therapy can improve prognosis in patients with AF.

Keywords

Atrial Fibrillation, Sinus rhythmcontrol, ablation

\section{Open Peer Review \\ Approval Status \\ 1 \\ 2 \\ version 1 \\ 03 Oct 2017 \\ Faculty Reviews are review articles written by the prestigious Members of Faculty Opinions. The articles are commissioned and peer reviewed before publication to ensure that the final, published version is comprehensive and accessible. The reviewers who approved the final version are listed with their names and affiliations.}

1. Andrea Natale, St. David's Medical Center, Austin, USA

2. Shih-Ann Chen, Taipei Veterans General Hospital, Taipei, Taiwan National Yang-Ming University, Taipei, Taiwan Any comments on the article can be found at the end of the article. 
Corresponding author: Paulus Kirchhof (p.kirchhof@bham.ac.uk)

Competing interests: $\mathrm{BO}$ is the chair of the Data and Safety Monitoring Board for the REDUCE-IT trial sponsored by Amarin, a national coordinator for the GLORIA-AF trial sponsored by Boehringer Ingelheim, and a speaker and consultant for On-X/Cryolife and Lundbeck. PK receives research support from the European Union, the British Heart Foundation, the Leducq Foundation, the Medical Research Council (UK), and the German Centre for Cardiovascular Research and from several drug and device companies active in atrial fibrillation and has received honoraria from several such companies. PK is listed as inventor on two patents held by the University of Birmingham (Atrial Fibrillation Therapy WO 2015140571 and Markers for Atrial Fibrillation WO 2016012783). RB declares that he has no competing interests

Grant information: This work was partially supported by the European Union (grant agreement 633196 [Characterising Afib by Translating its Causes into Health Modifiers in the Elderly] to PK), the British Heart Foundation (FS/13/43/30324 to PK), and the Leducq Foundation to PK.

The funders had no role in study design, data collection and analysis, decision to publish, or preparation of the manuscript.

Copyright: $\odot 2017$ Bond R et al. This is an open access article distributed under the terms of the Creative Commons Attribution License, which permits unrestricted use, distribution, and reproduction in any medium, provided the original work is properly cited.

How to cite this article: Bond R, Olshansky $B$ and Kirchhof $P$. Recent advances in rhythm control for atrial fibrillation [version 1; peer review: 2 approved] F1000Research 2017, 6(F1000 Faculty Rev):1796 https://doi.org/10.12688/f1000research.11061.1

First published: 03 Oct 2017, 6(F1000 Faculty Rev):1796 https://doi.org/10.12688/f1000research.11061.1 


\section{Introduction}

Atrial fibrillation (AF) remains a difficult management problem. The restoration and maintenance of sinus rhythm - rhythm control therapy - can markedly improve symptoms and haemodynamics for patients who have paroxysmal or persistent $\mathrm{AF}$, but some patients fare well with rate control alone ${ }^{1-4}$. AF can be a cause for impaired exercise capacity ${ }^{3}$, dementia, hypotension, syncope, dyspnoea, and heart failure, among other problems ${ }^{1,5}$, and is a major risk factor for ischaemic stroke $\mathrm{e}^{1-4}$. In addition, $\mathrm{AF}$ is associated with a higher risk of death in long-term follow-up ${ }^{2,4-6}$.

AF management involves reducing stroke risk and improving symptoms and functionality. Oral anticoagulation (OAC) can prevent the majority of ischaemic strokes from $\mathrm{AF}$ in at-risk patients $^{2,7}$. Controlling the ventricular rate during AF can improve patients' symptoms, but the maintenance of sinus rhythm is necessary for complete improvement in some patients. Techniques to restore sinus rhythm include pharmacological cardioversion with anti-arrhythmic drugs (AADs) and electrical cardioversion (performed with external defibrillation pads or an internal cardioversion catheter $)^{8}$. Catheter and surgical ablation can prevent $\mathrm{AF}$ recurrence ${ }^{2,9}$. This review will discuss the current and recent advances in catheter ablation for rhythm control of AF.

\section{Classification of atrial fibrillation}

AF is classified as first detected episode, paroxysmal (spontaneously terminates or cardioverted in less than 7 days), persistent (AF lasting for more than 7 days or requiring pharmacological or electrical cardioversion), longstanding persistent (continuous $\mathrm{AF}$ for over 1 year when it is decided to adopt a rhythm control strategy), or permanent (when AF is accepted and rhythm control is no longer pursued $)^{2,10}$. These definitions are used to guide treatment options for patients and also inclusion criteria for clinical trials $^{11,12}$

$\mathrm{AF}$ is often a chronic progressive disease, and animal studies have shown that "AF begets AF" 13,14 . In many patients, AF progresses as per currently accepted definitions; however, studies using implantable devices have shown that in some patients AF remains paroxysmal rather than progressing and persistent $\mathrm{AF}$ may regress to paroxysmal $^{15,16}$. Furthermore, data from continued atrial rhythm monitoring using implantable devices have shown that a patient's clinical AF classification poorly reflects the temporal persistence and suggests that the AF burden does not differ between patients with paroxysmal or persistent $\mathrm{AF}^{17}$. This may have implications for ablation strategy and inclusion criteria in clinical trials.

\section{Indications for catheter ablation of atrial fibrillation}

Catheter ablation can be useful in patients with symptomatic paroxysmal, persistent, and longstanding persistent AF that is refractory to or where there is an intolerance to AADs ${ }^{2,9}$. Catheter ablation is more effective than AADs in maintaining sinus rhythm ${ }^{18-22}$. Catheter ablation is also effective for restoring sinus rhythm in patients with $\mathrm{AF}$ and heart failure, improving left ventricular ejection fraction and quality of life $\mathrm{e}^{23,24}$. There is no current indication for catheter ablation to prevent cardiovascular outcomes or desired withdrawal of anticoagulation ${ }^{2}$. Patients are anticoagulated for the procedure either with uninterrupted warfarin aiming for an international normalised ratio of 2-3 or with an interrupted novel OAC (NOAC). Recent published trials comparing uninterrupted warfarin with uninterrupted NOACs for catheter ablation have had similar safety profiles ${ }^{25,26}$, and another trial comparing uninterrupted apixaban with uninterrupted warfarin is ongoing ${ }^{27}$. Anticoagulation is continued for at least 8 weeks after the procedure. The decision to stop anticoagulation is based on the risk profile of the patients using general anticoagulation guidelines (for example, $\mathrm{CHADS}_{2}-\mathrm{VASc} 2$ ) rather than the presumed rhythm outcome $^{2}$. However, ongoing trials are investigating stopping anticoagulation after a successful ablation ${ }^{28}$.

\section{Catheter ablation of atrial fibrillation}

$\mathrm{AF}$ is often initiated by ectopic beats arising from the pulmonary veins (PVs), although non-PV triggers (such as the superior vena cava $[\mathrm{SVC}]$, posterior left atrial free wall, crista terminalis, coronary sinus, and ligament of Marshall) have been described by several studies ${ }^{29-34}$. Furthermore, other arrhythmia mechanisms, most notably micro-re-entry and other re-entrant patterns of atrial excitation, contribute to the initiation and maintenance of $\mathrm{AF}^{35}$. The first successful reports of catheter ablation of AF targeted the triggering ectopic beats originating from the PVs preventing $\mathrm{AF}^{29,30}$. However, ablation within the $\mathrm{PVs}$ was associated with PV stenosis. It was recognised additionally that AF could also be initiated and maintained by PV antral tissue ${ }^{36-38}$. This led to electrical isolation of the PVs from the left atrium (PV isolation [PVI]) by either segmental PV ablation or, more commonly, wide area circumferential ablation (WACA) isolating the right and left PVs in pairs some distance from the venous tissue guided by $3 \mathrm{D}$ electro-anatomical mapping $(\mathrm{EAM})^{39,40}$. 3D EAM uses an electromagnetic or impedance-based catheter location method to create a 3D anatomic shell of the atria ${ }^{41}$. 3D EAM allows accurate visualisation of catheters within the anatomical shell without the use of fluoroscopy, which has led to a reduction in fluoroscopy time, procedure time, and radiation dose to the patient and operator ${ }^{42-45}$. There are three main mapping systems available: CARTO $^{\circledR}$ (Biosense Webster, Diamond Bar, CA, USA), EnSite ${ }^{\mathrm{TM}}$ NavX $^{\mathrm{TM}}$ (St. Jude Medical, Sylmar, CA, USA), and Rhythmia ${ }^{\mathrm{TM}}$ (Boston Scientific, Marlborough, MA, USA).

PVI remains the cornerstone of the AF ablation technique and is most commonly performed by point-by-point radiofrequency ablation $^{46,47}$. However, whilst acute PVI may appear to be present after lesion delivery, there may be PV connection that is not evident because of local oedema masking conduction rather than actual tissue necrosis during the ablation ${ }^{48}$. Furthermore, suboptimal contact force between catheter tip and atrial tissue during ablation is believed to reduce efficacy, although formal testing of this hypothesis is awaited. Contact force technology has been developed to allow instant feedback to the operator to allow adequate contact to deliver durable lesion without excessive force, which could lead to mechanical injury. Contact force technology has led to a significant reduction in AF recurrences and has reduced fluoroscopy and procedure times ${ }^{49}$. Point-by-point radiofrequency ablation is complex and technically demanding, requires extensive training, and is largely limited to specialist centres ${ }^{47,48}$. The most commonly used alternative to point-by-point radiofrequency ablation is the cryoballoon ablation catheter, which creates a circular lesion 
(producing necrosis by freezing) around each PV and is associated with similar outcomes in paroxysmal $\mathrm{AF}^{47,50}$. Cryoballoon ablation is a simpler technique that can be associated with shorter procedural times but increased fluoroscopy times ${ }^{47,51}$. Cryoballoon ablation is now commonly used to isolate the PVs. Other balloon-mounted technologies developed for AF ablation are the high-intensity focussed ultrasound (HIFU) balloon, radiofrequency "hot" balloon, and visually guided laser balloon (VGLB) ${ }^{48,52,53}$. Transvenous HIFU was demonstrated to be effective but was removed from the market owing to an unacceptable complication rate, including fatal atrial-oesophageal fistulas ${ }^{9}$, but there may be a role for epicardial HIFU in surgical AF ablations ${ }^{54}$. The radiofrequency "hot" balloon has shown promise but is still undergoing clinical trials. VGLB has been approved for use in Europe and permits direct visualisation of the target atrial tissue during ablation and is associated with good short-term outcomes ${ }^{48,55}$.

\section{Techniques for atrial fibrillation ablation}

Durable PVI is accepted as an effective treatment for paroxysmal AF with 60-80\% maintenance of sinus rhythm at 1 year and approximately equal to $50 \%$ at 5 years after a single procedure ${ }^{47,50,56-58}$. Ablation of non-PV triggers (SVC, posterior left atrial free wall, crista terminalis, coronary sinus, and ligament of Marshall) is usually performed if there is recurrent AF despite isolated PVs. Non-PV triggers can be identified by using isoproterenol infusion,

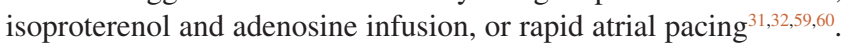
Ablation of non-PV triggers that still induced AF, after PVI, improved ablation outcomes in normal hearts and those with reduced ejection fraction ${ }^{59,60}$.

Results in those patients presenting with non-paroxysmal AF have lower success rates: $36-60 \%$ maintenance of sinus rhythm at 1 year and $20-42 \%$ long term after a single procedure ${ }^{12,57,61-63}$. Of note, some patients presenting with persistent AF have good long-term outcomes after AF ablation whereas other patients who present with paroxysmal AF have frequent and early recurrences. The structural remodelling that takes place in non-paroxysmal AF creates a substrate that maintains the arrhythmia and is believed to underlie recurrences when isolation of the PVs was successful ${ }^{64}$. Previous ablation techniques have aimed to target this substrate (substrate modification) in addition to PVI by either ablating complex atrial signals, so-called complex fractionated atrial electrograms (CFAEs), or creating linear lesions in the left atrium-a roof line connecting the lesions around the left and right upper superior veins, a mitral isthmus line connecting the mitral valve annulus and left inferior PV, and an anterior line connecting either the anterior left upper PV or the right upper PV to the mitral valve annulus ${ }^{9,12}$. In longstanding persistent AF, a "stepwise" approach has been described $^{65}$. This starts with PVI followed by isolation of other thoracic veins-superior vena cava and coronary sinus. This is followed by ablation of CFAEs and then lines including a cavotricuspid line, roof line, and mitral isthmus line. At each step, if there is cardioversion to sinus rhythm, then ablation is stopped. Ablation techniques for persistent AF have longer procedure times and are associated with left atrial macro re-entrant tachycardia in $25 \%$ of patients ${ }^{2}$.
Recently, the Substrate and Trigger Ablation for Reduction of Atrial Fibrillation Trial Part II (STAR AF 2 trial) compared three approaches to the ablation of persistent AF: PVI alone, PVI plus CFAEs, and PVI plus a roof and mitral isthmus line ${ }^{12}$. The results of this study were quite surprising and showed no difference in outcomes between the three ablation strategies, illustrating the effectiveness of PVI for sinus rhythm maintenance in patients with AF. After 18 months of follow-up, 59\% of patients assigned to PVI alone were AF-free compared with $49 \%$ of patients assigned to PVI plus CFAE ablation and $46 \%$ of patients assigned to PVI plus a roof and mitral isthmus line. A meta-analysis was performed incorporating data from STAR AF 2 as well as nine other studies with 1,821 patients included ${ }^{66}$. In comparison with PVI alone, CFAE ablation and linear lesions offered no significant improvement in arrhythmia-free survival. This landmark trial has changed the way many perform ablations for persistent AF, supporting the use of PVI alone as a first-line therapy, which in the future could be performed by cryoballoon or VGLB ${ }^{67}$. In fact, in a recent survey, the majority of centres (67\%) were performing PVI alone as a first procedure in persistent $\mathrm{AF}$, and over half of centres surveyed responded that the STAR AF 2 results had changed their strategy for persistent AF ablation $^{68}$. New ablation strategies for the ablation of persistent AF continue to be developed. A technique to target sources or "rotors" of AF using a multi-electrode basket catheter showed initial promise with at least $80 \%$ freedom from $\mathrm{AF}$ at a year ${ }^{69,70}$; however, these results have not been replicated ${ }^{71-74}$. Interestingly, the CONFIRM (Conventional Ablation for Atrial Fibrillation With or Without Focal Impulse and Rotor Modulation) study also demonstrated that $45 \%$ of AF sources were coincidentally ablated with conventional ablation for persistent AF (WACA and roof line), which may also explain why some patients do well after PVI whereas others may need more extensive ablation ${ }^{70}$. A non-invasive vest comprising 252 body surface electrodes has also been developed to identify rotors; this technique records atrial epicardial electrograms, and a non-contrast computed tomography (CT) scan is used to produce anatomy and electrode position ${ }^{75,76}$. Another strategy recently described is scar homogenisation, where low-voltage areas in the atria thought to represent fibrosis are ablated ${ }^{77,78}$. These ablation strategies are still under development and have not been compared with PVI alone in randomised controlled multicentre trials. At present, PVI as first-line therapy for persistent AF is recommended $^{2}$.

\section{Complications of catheter ablation of atrial fibrillation} A total of 5 to $7 \%$ of patients will suffer a complication after catheter ablation of $\mathrm{AF}^{2,79}$. The most frequent complications are related to vascular access and usually can be managed conservatively ${ }^{80}$. The most important severe complications are stroke/transient ischaemic attack $(<1 \%)$, cardiac tamponade $(1 \%)$, and phrenic nerve injury (0.001-3\% depending on ablation energy used). PV stenosis, atrio-oesophageal fistula, and death are all rare r, $12,47,79,81$. Vascular access complications potentially can be reduced by using ultrasound to image the femoral veins ${ }^{80}$. Atrio-oesophageal fistulas are difficult to diagnose. Patients present with infection without a clear focus, pleuritic chest pain, stroke, or convulsions ${ }^{82}$. Transoesophageal echo should 
be avoided, and diagnosis is by CT scan with emergent cardiac surgery as the treatment of choice, although temporary stenting of the oesophagus has been used in early diagnoses ${ }^{83,84}$.

\section{Surgical ablation of atrial fibrillation}

The Cox maze procedure for the surgical treatment of AF was first used in 1987 and involves the creation of atrial incisions (around the PVs and posterior left atrium, connecting to the mitral annulus, cavotricuspid isthmus, and cavocaval connection, and exclusion of the left atrial appendage), which prevents atrial re-entry and allows the sinus impulse to activate the entire atrial myocardium ${ }^{85}$. The long-term outcomes of 198 patients who underwent surgery, either as a standalone treatment for AF or in conjunction with other cardiac surgery, are excellent ${ }^{86}$, although the rhythm follow-up has been less rigorous than in controlled clinical trials. Despite its efficacy, the original Cox maze procedure is complex and technically difficult and is associated with a high incidence of major complications $(12 \%)$, including three perioperative deaths and three perioperative strokes ${ }^{9,86}$. This has led to less-invasive techniques and hybrid procedures. Atrial incisions have been replaced with linear lines of ablation with radiofrequency energy, cryoablation, or HIFU and can be performed via mini-thoractomy ${ }^{2,9}$. In one trial, the results of minimally invasive surgical ablation were better than catheter ablation but with a significant increase in complications ${ }^{87}$. In an attempt to improve outcomes further, a "hybrid" approach, which combines a thorascopic epicardial with percutaneous endocardial catheter ablation, has recently been described ${ }^{88,89}$. Initial results have been excellent, but more trials are needed and the complication rates from surgery may make the procedure prohibitive for standalone AF but may be useful in those undergoing other cardiac surgery.

\section{Hybrid rhythm control therapy}

AADs are continued after a catheter ablation for 8-12 weeks during the so-called "blanking period" early recurrence of atrial tachyarrhythmias whilst scar formation from ablation lesions takes place ${ }^{2,91}$. Evidence supporting this strategy is provided by the AMIO-CAT (amiodarone after catheter ablation for atrial fibrillation) study, which randomly assigned patients to either short-term amiodarone or placebo and demonstrated a significant reduction in early recurrence of AF during the blanking period in the amiodarone group ${ }^{91}$. After the blanking period, it is common practice to stop AADs. However, catheter ablation with continued use of an AAD is associated with fewer recurrences of atrial tachyarrhythmias, and this includes AADs previously reported as ineffective ${ }^{90,92}$. Therefore, it would seem reasonable to continue on AADs after an ablation or to restart AADs if there is a single recurrence of $\mathrm{AF}$, although in reality most patients would like to stop their AADs.

\section{Future directions}

Pursuing sinus rhythm in patients with AF is recommended for those who are symptomatic, although we still do not know whether it confers any prognostic benefit (that is, reducing stroke risk and mortality). Ongoing trials have been designed to answer this. EAST-AFNET 4 (Early treatment of Atrial fibrillation for Stroke prevention Trial) has enrolled over 2,500 patients and will test whether an early, comprehensive, rhythm control using either AADs or catheter ablation prevents adverse cardiovascular outcomes compared with usual care ${ }^{93}$. CABANA (Catheter Ablation versus Anti-arrhythmic Drug Therapy for Atrial Fibrillation Trial) will test the hypothesis that catheter ablation of $\mathrm{AF}$ is better than rate control or rhythm control with AADs at decreasing the incidence of mortality, disabling stroke, serious bleeding, or cardiac arrest ${ }^{94}$.

We also do not know what the best strategy for catheter ablation of persistent AF is. For now, it is recommended that PVI alone be performed for the first ablation procedure for persistent AF. However, further trials are needed, including trials comparing PVI alone with novel ablation techniques using multi-electrode basket catheters or vests to map rotors.

\section{Competing interests}

BO is the chair of the Data and Safety Monitoring Board for the REDUCE-IT trial sponsored by Amarin, a national coordinator for the GLORIA-AF trial sponsored by Boehringer Ingelheim, and a speaker and consultant for On-X/Cryolife and Lundbeck. PK receives research support from the European Union, the British Heart Foundation, the Leducq Foundation, the Medical Research Council (UK), and the German Centre for Cardiovascular Research and from several drug and device companies active in atrial fibrillation and has received honoraria from several such companies. PK is listed as inventor on two patents held by the University of Birmingham (Atrial Fibrillation Therapy WO 2015140571 and Markers for Atrial Fibrillation WO 2016012783). $\mathrm{RB}$ declares that he has no competing interests

\section{Grant information}

This work was partially supported by the European Union (grant agreement 633196 [Characterising Afib by Translating its Causes into Health Modifiers in the Elderly] to PK), the British Heart Foundation (FS/13/43/30324 to PK), and the Leducq Foundation to PK.

The funders had no role in study design, data collection and analysis, decision to publish, or preparation of the manuscript.
1. F Miyasaka $\mathrm{Y}$, Barnes ME, Gersh BJ, et al.: Secular trends in incidence of atrial fibrillation in Olmsted County, Minnesota, 1980 to 2000, and implications on the projections for future prevalence. Circulation. 2006; 114(2): 119-25. PubMed Abstract | Publisher Full Text | F1000 Recommendation
2. Kirchhof $P$, Benussi $S$, Kotecha D, et al.: 2016 ESC Guidelines for the management of atrial fibrillation developed in collaboration with EACTS. Europace. 2016; 18(11): 1609-78.

PubMed Abstract | Publisher Full Text 
3. Go AS, Hylek EM, Phillips KA, et al.: Prevalence of diagnosed atrial fibrillation in adults: national implications for rhythm management and stroke prevention: the AnTicoagulation and Risk Factors in Atrial Fibrillation (ATRIA) Study. JAMA. 2001; 285(18): 2370-5.

PubMed Abstract | Publisher Full Text

4. Wolf PA, Benjamin EJ, Belanger AJ, et al:: Secular trends in the prevalence of atrial fibrillation: The Framingham Study. Am Heart J. 1996; 131(4): 790-5. PubMed Abstract | Publisher Full Text

5. Benjamin EJ, Chen PS, Bild DE, et al.: Prevention of atrial fibrillation: report from a national heart, lung, and blood institute workshop. Circulation. 2009; 119(4): 606-18.

PubMed Abstract | Publisher Full Text | Free Full Text

6. Benjamin EJ, Wolf PA, D'Agostino RB, et al:: Impact of atrial fibrillation on the risk of death: the Framingham Heart Study. Circulation. 1998; 98(10): 946-52. PubMed Abstract | Publisher Full Text

7. F Hart RG, Pearce LA, Aguilar MI: Meta-analysis: antithrombotic therapy to prevent stroke in patients who have nonvalvular atrial fibrillation. Ann Intern Med. 2007; 146(12): 857-67.

PubMed Abstract | Publisher Full Text | F1000 Recommendation

8. Boriani G, Biffi M, Camanini C, et al:: Transvenous internal cardioversion fo atrial fibrillation: a randomized comparison between catheters with different coil length. Am Heart J. 2002; 144(5): 851-7.

PubMed Abstract | Publisher Full Text

9. Calkins H, Kuck KH, Cappato R, et al:: 2012 HRS/EHRA/ECAS expert consensus statement on catheter and surgical ablation of atrial fibrillation: recommendations for patient selection, procedural techniques, patient management and follow-up, definitions, endpoints, and research trial design. J Interv Card Electrophysiol. 2012; 33(2): 171-257.

PubMed Abstract | Publisher Full Text

10. January CT, Wann LS, Alpert JS, et al.: 2014 AHA/ACC/HRS guideline for the management of patients with atrial fibrillation: executive summary: a report of the American College of Cardiology/American Heart Association Task Force on practice guidelines and the Heart Rhythm Society. Circulation. 2014; 130(23): 2071-104.

PubMed Abstract | Publisher Full Text

11. F Cosedis Nielsen J, Johannessen A, Raatikainen $\mathrm{P}$, et al: Radiofrequency ablation as initial therapy in paroxysmal atrial fibrillation. N Engl J Med. 2012; 367(17): 1587-95.

PubMed Abstract | Publisher Full Text | F1000 Recommendation

12. Verma A, Jiang CY, Betts TR, et al:: Approaches to catheter ablation for persistent atrial fibrillation. N Engl J Med. 2015; 372(12): 1812-22. PubMed Abstract | Publisher Full Text

13. Wijffels MC, Kirchhof CJ, Dorland R, et al:: Atrial fibrillation begets atrial fibrillation. A study in awake chronically instrumented goats. Circulation. 1995 92(7): 1954-68.

PubMed Abstract | Publisher Full Text

14. Lu Z, Scherlag BJ, Lin J, et al:: Atrial fibrillation begets atrial fibrillation: autonomic mechanism for atrial electrical remodeling induced by short-term rapid atrial pacing. Circ Arrhythm Electrophysiol. 2008; 1(3): 184-92. PubMed Abstract | Publisher Full Text | Free Full Text

15. F Veasey RA, Sugihara C, Sandhu K, et al:: The natural history of atrial fibrillation in patients with permanent pacemakers: is atrial fibrillation a progressive disease? J Interv Card Electrophysiol. 2015; 44(1): 23-30. PubMed Abstract | Publisher Full Text | F1000 Recommendation

16. Jahangir A, Lee V, Friedman PA, et al:: Long-term progression and outcomes with aging in patients with lone atrial fibrillation: a 30-year follow-up study. Circulation. 2007; 115(24): 3050-6.

PubMed Abstract | Publisher Full Text

17. Charitos El, Pürerfellner H, Glotzer TV, et al.: Clinical classifications of atrial fibrillation poorly reflect its temporal persistence: insights from 1,195 patients continuously monitored with implantable devices. J Am Coll Cardiol. 2014; 63(25 Pt A): $2840-8$. PubMed Abstract | Publisher Full Text

18. F Scherr D, Khairy P, Miyazaki S, et al.: Five-year outcome of catheter ablation of persistent atrial fibrillation using termination of atrial fibrillation as a procedural endpoint. Circ Arrhythm Electrophysiol. 2015; 8(1): 18-24. PubMed Abstract | Publisher Full Text | F1000 Recommendation

19. Mont L, Bisbal F, Hernández-Madrid A, et al:: Catheter ablation vs. antiarrhythmic drug treatment of persistent atrial fibrillation: a multicentre, randomized, controlled trial (SARA study). Eur Heart J. 2014; 35(8): 501-7. PubMed Abstract | Publisher Full Text | Free Full Text

20. F Schreiber D, Rostock T, Fröhlich M, et al.: Five-year follow-up after catheter ablation of persistent atrial fibrillation using the stepwise approach and prognostic factors for success. Circ Arrhythm Electrophysiol. 2015; 8(2): 308-17. PubMed Abstract | Publisher Full Text | F1000 Recommendation

21. F Jaïs $\mathrm{P}$, Cauchemez B, Macle L, et al:: Catheter ablation versus antiarrhythmic drugs for atrial fibrillation: the A4 study. Circulation. 2008; 118(24): 2498-505

PubMed Abstract | Publisher Full Text | F1000 Recommendation

22. F Pappone C, Augello G, Sala S, et al: A randomized trial of circumferential pulmonary vein ablation versus antiarrhythmic drug therapy in paroxysmal atrial fibrillation: the APAF Study. J Am Coll Cardiol. 2006; 48(11): 2340-7. PubMed Abstract | Publisher Full Text | F1000 Recommendation

23. Hunter RJ, Berriman TJ, Diab I, et al:: A randomized controlled trial of catheter ablation versus medical treatment of atrial fibrillation in heart failure (the CAMTAF trial). Circ Arrhythm Electrophysiol. 2014; 7(1): 31-8. PubMed Abstract | Publisher Full Text

24. F Jones DG, Haldar SK, Hussain W, et al.: A randomized trial to assess catheter ablation versus rate control in the management of persistent atria fibrillation in heart failure. J Am Coll Cardiol. 2013; 61(18): 1894-903. PubMed Abstract | Publisher Full Text | F1000 Recommendation

25. F Calkins H, Willems S, Gerstenfeld EP, et al:: Uninterrupted Dabigatran versus Warfarin for Ablation in Atrial Fibrillation. N Engl J Med. 2017; 376(17) $1627-36$

PublMed Abstract | Publisher Full Text | F1000 Recommendation

26. F Cappato R, Marchlinski FE, Hohnloser SH, et al.: Uninterrupted rivaroxaban vs. uninterrupted vitamin $\mathrm{K}$ antagonists for catheter ablation in non-valvular atrial fibrillation. Eur Heart J. 2015; 36(28): 1805-11.

PubMed Abstract | Publisher Full Text | Free Full Text | F1000 Recommendation

27. Di Biase L, Callans D, Hæusler KG, et al.: Rationale and design of AXAFA-AFNET 5: an investigator-initiated, randomized, open, blinded outcome assessment, multi-centre trial to comparing continuous apixaban to vitamin $\mathrm{K}$ antagonists in patients undergoing atrial fibrillation catheter ablation. Europace. 2017; 19(1): 132-8. 19(1): 132-8.
PubMed Abstract | Publisher Full Text

28. ClinicalTrials.gov: Optimal Anticoagulation for Higher Risk Patients Post-Catheter Ablation for Atrial Fibrillation Trial (OCEAN). (21 April 2017). Reference Source

29. Haïssaguerre M, Jaïs $P$, Shah DC, et al:: Spontaneous initiation of atrial fibrillation by ectopic beats originating in the pulmonary veins. N Engl $J$ Med. 1998; 339(10): 659-66.

PubMed Abstract | Publisher Full Text

30. Chen SA, Hsieh MH, Tai CT, et al:: Initiation of atrial fibrillation by ectopic beats originating from the pulmonary veins: electrophysiological characteristics, pharmacological responses, and effects of radiofrequency ablation. Circulation. 1999; 100(18): 1879-86. PubMed Abstract | Publisher Full Text

31. Lin WS, Tai CT, Hsieh MH, et al:: Catheter ablation of paroxysmal atrial fibrillation initiated by non-pulmonary vein ectopy. Circulation. 2003; 107(25): 3176-83.

PubMed Abstract | Publisher Full Text

32. Tsai CF, Tai CT, Hsieh MH, et al:: Initiation of atrial fibrillation by ectopic beats originating from the superior vena cava: electrophysiological characteristics and results of radiofrequency ablation. Circulation. 2000; 102(1): 67-74. PubMed Abstract | Publisher Full Text

33. Pastor A, Núñez A, Magalhaes A, et al:: [The superior vena cava as a site of ectopic foci in atrial fibrillation]. Rev Esp Cardiol. 2007; 60(1): 68-71. PubMed Abstract | Publisher Full Text

34. Hwang C, Wu TJ, Doshi RN, et al.: Vein of marshall cannulation for the analysis of electrical activity in patients with focal atrial fibrillation. Circulation. 2000 101(13): 1503-5.

PubMed Abstract | Publisher Full Text

35. Schotten $\mathrm{U}$, Verheule $\mathrm{S}$, Kirchhof $\mathrm{P}$, et al:: Pathophysiological mechanisms of atrial fibrillation: a translational appraisal. Physiol Rev. 2011; 91(1): 265-325. PubMed Abstract | Publisher Full Text

36. Robbins IM, Colvin EV, Doyle TP, et al: Pulmonary vein stenosis after catheter ablation of atrial fibrillation. Circulation. 1998; 98(17): 1769-75. PubMed Abstract | Publisher Full Text

37. Marrouche NF, Martin DO, Wazni O, et al.: Phased-array intracardiac echocardiography monitoring during pulmonary vein isolation in patients with atrial fibrillation: impact on outcome and complications. Circulation. 2003; 107(21): 2710-6.

PubMed Abstract | Publisher Full Text

38. Kanj M, Wazni O, Natale A: Pulmonary vein antrum isolation. Heart Rhythm. 2007: 4(3 Suppl): S73-9.

PubMed Abstract | Publisher Full Text

39. Oral $\mathrm{H}$, Scharf $\mathrm{C}$, Chugh $\mathrm{A}$, et al:: Catheter ablation for paroxysmal atrial fibrillation: segmental pulmonary vein ostial ablation versus left atrial ablation. Circulation. 2003; 108(19): 2355-60. PubMed Abstract | Publisher Full Text

40. Pappone $\mathrm{C}$, Rosanio $\mathrm{S}$, Oreto $\mathrm{G}$, et al:: Circumferential radiofrequency ablation of pulmonary vein ostia: A new anatomic approach for curing atrial fibrillation. Circulation. 2000; 102(21): 2619-28.

PubMed Abstract | Publisher Full Text

41. Del Carpio Munoz F, Buescher TL, Asirvatham SJ: Three-dimensional mapping of cardiac arrhythmias: what do the colors really mean? Circ Arrhythm Electrophysiol. 2010; 3(6): e6-11.

PubMed Abstract | Publisher Full Text

42. Estner HL, Deisenhofer I, Luik A, et al.: Electrical isolation of pulmonary veins in patients with atrial fibrillation: reduction of fluoroscopy exposure and procedure duration by the use of a non-fluoroscopic navigation system (NavX). Europace. 2006; 8(8): 583-7.

PubMed Abstract | Publisher Full Text 
43. Stabile G, Scaglione M, del Greco M, et al:: Reduced fluoroscopy exposure during ablation of atrial fibrillation using a novel electroanatomical navigation system: a multicentre experience. Europace. 2012; 14(1): 60-5.

PubMed Abstract | Publisher Full Text

44. Bhakta D, Miller JM: Principles of electroanatomic mapping. Indian Pacing Electrophysiol J. 2008; 8(1): 32-50. PubMed Abstract | Free Full Text

45. Knackstedt $\mathrm{C}$, Schauerte $\mathrm{P}$, Kirchhof $\mathrm{P}$ : Electro-anatomic mapping systems in arrhythmias. Europace. 2008; 10 Suppl 3: iii28-34. PubMed Abstract | Publisher Full Text

46. Mahida S, Berte B, Yamashita S, et al: New Ablation Technologies and Techniques. Arrhythm Electrophysiol Rev. 2014; 3(2): 107-112. PubMed Abstract | Publisher Full Text | Free Full Text

47. Kuck K, Brugada J, Fürnkranz A, et al.: Cryoballoon or Radiofrequency Ablation for Paroxysmal Atrial Fibrillation. N Engl J Med. 2016; 374(23): 2235-45. PubMed Abstract | Publisher Full Text

48. Bhardwaj R, Reddy VY: Visually-guided Laser Balloon Ablation of Atrial Fibrillation: A "Real World" Experience. Rev Esp Cardiol (Engl Ed). 2016; 69(5): 474-6.

PubMed Abstract | Publisher Full Text

49. F Shurrab M, Di Biase L, Briceno DF, et al:: Impact of Contact Force Technology on Atrial Fibrillation Ablation: A Meta-Analysis. J Am Heart Assoc. 2015; 4(9): e002476.

PubMed Abstract | Publisher Full Text | Free Full Text | F1000 Recommendation

50. F Luik A, Radzewitz A, Kieser M, et al.: Cryoballoon Versus Open Irrigated Radiofrequency Ablation in Patients With Paroxysmal Atrial Fibrillation: The Prospective, Randomized, Controlled, Noninferiority FreezeAF Study. Circulation. 2015; 132(14): 1311-9.

PubMed Abstract | Publisher Full Text | Free Full Text | F1000 Recommendation

51. F Hunter RJ, Baker V, Finlay MC, et al:: Point-by-Point Radiofrequency Ablation Versus the Cryoballoon or a Novel Combined Approach: A Randomized Trial Comparing 3 Methods of Pulmonary Vein Isolation for Paroxysmal Atrial Fibrillation (The Cryo Versus RF Trial). J Cardiovasc Electrophysiol. 2015; 26(12): 1307-14.

PubMed Abstract | Publisher Full Text | F1000 Recommendation

52. Andrikopoulos G, Tzeis S, Vardas PE: Invasive therapy for atrial fibrillation: recent developments in ablation, navigation and mapping technology. Heart. 2011; 97(3): 237-43.

PubMed Abstract | Publisher Full Text

53. F Yamaguchi $\mathrm{Y}$, Sohara $\mathrm{H}$, Takeda $\mathrm{H}$, et al:: Long-Term Results of Radiofrequency Hot Balloon Ablation in Patients With Paroxysmal Atrial Fibrillation: Safety and Rhythm Outcomes. J Cardiovasc Electrophysiol. 2015; 26(12): 1298-306.

PubMed Abstract | Publisher Full Text | F1000 Recommendation

54. F Singh S, Nair KK, Koruth JS, et al.: The role of high-intensity focused ultrasound in ablation of atrial fibrillation and other cardiac arrhythmias. RRFU. 2015; 3: 11-18.

Publisher Full Text | F1000 Recommendation

55. Dukkipati SR, Neuzil P, Skoda J, et al:: Visual balloon-guided point-by-poin ablation: reliable, reproducible, and persistent pulmonary vein isolation. Circ Arrhythm Electrophysiol. 2010; 3(3): 266-73.

PubMed Abstract | Publisher Full Text

56. Ouyang F, Tilz R, Chun J, et al:: Long-term results of catheter ablation in paroxysmal atrial fibrillation: lessons from a 5-year follow-up. Circulation. 2010; 122(23): 2368-77.

PubMed Abstract | Publisher Full Text

57. F Ganesan AN, Shipp NJ, Brooks AG, et al.: Long-term outcomes of catheter ablation of atrial fibrillation: a systematic review and meta-analysis. J Am Heart Assoc. 2013; 2(2): e004549.

PubMed Abstract | Publisher Full Text | Free Full Text | F1000 Recommendation

58. Tzou WS, Marchlinski FE, Zado ES, et al.: Long-term outcome after successful catheter ablation of atrial fibrillation. Circ Arrhythm Electrophysiol. 2010; 3(3): 237-42.

PubMed Abstract | Publisher Full Text

59. Elayi CS, Di Biase L, Bai R, et al:: Administration of isoproterenol and adenosine to guide supplemental ablation after pulmonary vein antrum isolation. J Cardiovasc Electrophysiol. 2013; 24(11): 1199-206. PubMed Abstract | Publisher Full Text

60. F Zhao Y, Di Biase L, Trivedi C, et al.: Importance of non-pulmonary vein triggers ablation to achieve long-term freedom from paroxysmal atrial fibrillation in patients with low ejection fraction. Heart Rhythm. 2016;13(1): $141-9$.

PubMed Abstract | Publisher Full Text | F1000 Recommendation

61. Tilz RR, Rillig A, Thum AM, et al:: Catheter ablation of long-standing persistent atrial fibrillation: 5-year outcomes of the Hamburg Sequential Ablation Strategy. J Am Coll Cardiol. 2012; 60(19): 1921-9.

PubMed Abstract | Publisher Full Text

62. Chao TF, Tsao HM, Lin YJ, et al:: Clinical outcome of catheter ablation in patients with nonparoxysmal atrial fibrillation: results of 3-year follow-up. Circ Arrhythm Electrophysiol. 2012; 5(3): 514-20.

PubMed Abstract | Publisher Full Text

63. Rostock T, Salukhe TV, Steven D, et al:: Long-term single- and multiple-procedure outcome and predictors of success after catheter ablation for persistent atrial fibrillation. Heart Rhythm. 2011; 8(9): 1391-7.

PubMed Abstract | Publisher Full Text

64. Iwasaki YK, Nishida K, Kato T, et al.: Atrial fibrillation pathophysiology: implications for management. Circulation. 2011; 124(20): 2264-74. PubMed Abstract | Publisher Full Text

65. Haïssaguerre M, Hocini M, Sanders $\mathrm{P}$, et al.: Catheter ablation of long-lasting persistent atrial fibrillation: clinical outcome and mechanisms of subsequent arrhythmias. J Cardiovasc Electrophysiol. 2005; 16(11): 1138-47. PubMed Abstract | Publisher Full Text

66. F Scott PA, Silberbauer J, Murgatroyd FD: The impact of adjunctive complex fractionated atrial electrogram ablation and linear lesions on outcomes in persistent atrial fibrillation: a meta-analysis. Europace. 2016; 18(3): 359-67. PubMed Abstract | Publisher Full Text | F1000 Recommendation

67. Kirchhof $\mathrm{P}$, Calkins $\mathrm{H}$ : Catheter ablation in patients with persistent atria fibrillation. Eur Heart J. 2017; 38(1): 20-6.

PubMed Abstract | Publisher Full Text | Free Full Text

68. F Dagres N, Bongiorni MG, Larsen TB, et al:: Current ablation techniques for persistent atrial fibrillation: results of the European Heart Rhythm Association Survey. Europace. 2015; 17(10): 1596-600.

PubMed Abstract | Publisher Full Text | F1000 Recommendation

69. F Narayan SM, Krummen DE, Shivkumar K, et al.: Treatment of atrial fibrillation by the ablation of localized sources: CONFIRM (Conventional Ablation for Atrial Fibrillation With or Without Focal Impulse and Rotor Modulation) trial. J Am Coll Cardiol. 2012; 60(7): 628-36.

PubMed Abstract | Publisher Full Text | Free Full Text | F1000 Recommendation

70. F Narayan SM, Krummen DE, Clopton $P$, et al:: Direct or coincidental elimination of stable rotors or focal sources may explain successful atrial fibrillation ablation: on-treatment analysis of the CONFIRM trial (Conventional ablation for AF with or without focal impulse and rotor modulation). J Am Coll Cardiol. 2013; 62(2): 138-47.

PubMed Abstract | Publisher Full Text | Free Full Text | F1000 Recommendation

71. Buch $\mathrm{E}$, Share $\mathrm{M}$, Tung R, et al.: Long-term clinical outcomes of focal impulse and rotor modulation for treatment of atrial fibrillation: A multicenter experience. Heart Rhythm. 2016; 13(3): 636-41.

PubMed Abstract | Publisher Full Text | Free Full Text

72. Steinberg JS, Shah $\mathrm{Y}$, Bhatt A, et al: Focal impulse and rotor modulation: Acute procedural observations and extended clinical follow-up. Heart Rhythm. 2017; 14(2): 192-7.

PubMed Abstract | Publisher Full Text

73. Gianni C, Mohanty S, Di Biase L, et al.: Acute and early outcomes of focal impulse and rotor modulation (FIRM)-guided rotors-only ablation in patients with nonparoxysmal atrial fibrillation. Heart Rhythm. 2016; 13(4): 830-5. PubMed Abstract | Publisher Full Text

74. Benharash $\mathrm{P}$, Buch $\mathrm{E}$, Frank $\mathrm{P}$, et al:: Quantitative analysis of localized sources identified by focal impulse and rotor modulation mapping in atrial fibrillation. Circ Arrhythm Electrophysiol. 2015; 8(3): 554-61.

PubMed Abstract | Publisher Full Text | Free Full Text

75. Ramanathan C, Ghanem RN, Jia P, et al:: Noninvasive electrocardiographic imaging for cardiac electrophysiology and arrhythmia. Nat Med. 2004; 10(4): 422-8.

PubMed Abstract | Publisher Full Text | Free Full Text

76. Haissaguerre M, Hocini M, Shah AJ, et al:: Noninvasive panoramic mapping of human atrial fibrillation mechanisms: a feasibility report. J Cardiovasc Electrophysiol. 2013; 24(6): 711-7. PubMed Abstract | Publisher Full Text

77. $\mathrm{F}$ Kottkamp H, Berg J, Bender R, et al:: Box Isolation of Fibrotic Areas (BIFA): A Patient-Tailored Substrate Modification Approach for Ablation of Atrial Fibrillation. J Cardiovasc Electrophysiol. 2016; 27(1): 22-30. PubMed Abstract | Publisher Full Text | F1000 Recommendation

78. Rolf S, Kircher S, Arya A, et al:: Tailored atrial substrate modification based on low-voltage areas in catheter ablation of atrial fibrillation. Circ Arrhythm Electrophysiol. 2014; 7(5): 825-33. PubMed Abstract | Publisher Full Text

79. Deshmukh A, Patel NJ, Pant S, et al:: In-hospital complications associated with catheter ablation of atrial fibrillation in the United States between 2000 and 2010: analysis of 93801 procedures. Circulation. 2013; 128(19): 2104-12. PubMed Abstract | Publisher Full Text

80. Wynn GJ, Haq I, Hung J, et al.: Improving safety in catheter ablation for atria fibrillation: a prospective study of the use of ultrasound to guide vascular access. J Cardiovasc Electrophysiol. 2014; 25(7): 680-5. PubMed Abstract | Publisher Full Text

81. Gupta A, Perera T, Ganesan A, et al:: Complications of catheter ablation of atrial fibrillation: a systematic review. Circ Arrhythm Electrophysiol. 2013; 6(6): 1082-8.

PubMed Abstract | Publisher Full Text

82. Pappone $\mathrm{C}$, Oral $\mathrm{H}$, Santinelli $\mathrm{V}$, et al:: Atrio-esophageal fistula as a complication of percutaneous transcatheter ablation of atrial fibrillation. Circulation. 2004; 109(22): 2724-6.

PubMed Abstract | Publisher Full Text

83. Bunch TJ, Nelson J, Foley $\mathrm{T}$, et al:: Temporary esophageal stenting allows healing of esophageal perforations following atrial fibrillation ablation 
procedures. J Cardiovasc Electrophysiol. 2006; 17(4): 435-9. PubMed Abstract | Publisher Full Text

84. Pappone C, Vicedomini G, Santinelli V: Atrio-Esophageal Fistula After AF Ablation: Pathophysiology, Prevention \&Treatment. J Atr Fibrillation. 2013; 6(3): 860 .

PubMed Abstract | Free Full Text

85. Cox JL, Schuessler RB, D'Agostino HJ Jr, et al.: The surgical treatment of atrial fibrillation. III. Development of a definitive surgical procedure. J Thorac Cardiovasc Surg. 1991; 101(4): 569-83.

PubMed Abstract

86. Prasad SM, Maniar HS, Camillo CJ, et al: The Cox maze III procedure for atrial fibrillation: long-term efficacy in patients undergoing lone versus concomitant procedures. J Thorac Cardiovasc Surg. 2003; 126(6): 1822-8.

PubMed Abstract | Publisher Full Text

87. Boersma LV, Castella M, van Boven W, et al.: Atrial fibrillation catheter ablation versus surgical ablation treatment (FAST): a 2-center randomized clinical trial. Circulation. 2012; 125(1): 23-30.

PubMed Abstract | Publisher Full Text

88. La Meir M, Gelsomino S, Lucà F, et al:: Minimally invasive surgical treatment of lone atrial fibrillation: early results of hybrid versus standard minimally invasive approach employing radiofrequency sources. Int J Cardiol. 2013; 167(4): 1469-75

PubMed Abstract | Publisher Full Text

89. Krul SP, Driessen AH, van Boven WJ, et al:: Thoracoscopic video-assisted pulmonary vein antrum isolation, ganglionated plexus ablation, and periprocedural confirmation of ablation lesions: first results of a hybrid surgical-electrophysiological approach for atrial fibrillation. Circ Arrhythm Electrophysiol. 2011; 4(3): 262-70.

PubMed Abstract | Publisher Full Text

90. Arbelo E, Brugada J, Hindricks G, et al.: The atrial fibrillation ablation pilot study: a European Survey on Methodology and results of catheter ablation for atrial fibrillation conducted by the European Heart Rhythm Association. Eur Heart J. 2014; 35(22): 1466-78.

PubMed Abstract | Publisher Full Text

91. Darkner S, Chen X, Hansen J, et al:: Recurrence of arrhythmia following shortterm oral AMIOdarone after CATheter ablation for atrial fibrillation: a doubleblind, randomized, placebo-controlled study (AMIO-CAT trial). Eur Heart J. 2014; 35(47): 3356-64.

PubMed Abstract | Publisher Full Text

92. Calkins $\mathrm{H}$, Reynolds MR, Spector $\mathrm{P}$, et al.: Treatment of atrial fibrillation with antiarrhythmic drugs or radiofrequency ablation: two systematic literature reviews and meta-analyses. Circ Arrhythm Electrophysiol. 2009; 2(4): 349-61. PubMed Abstract | Publisher Full Text

93. Kirchhof $\mathrm{P}$, Breithardt G, Camm AJ, et al.: Improving outcomes in patients with atrial fibrillation: rationale and design of the Early treatment of Atrial fibrillation for Stroke prevention Trial. Am Heart J. 2013; 166(3): 442-8. PubMed Abstract | Publisher Full Text

94. ClinicalTrials.gov: Catheter Ablation vs Anti-arrhythmic Drug Therapy for Atrial Fibrillation Trial (CABANA). (5 May 2016).

Reference Source 


\section{Open Peer Review}

\section{Current Peer Review Status:}

\section{Editorial Note on the Review Process}

Faculty Reviews are review articles written by the prestigious Members of Faculty Opinions. The articles are commissioned and peer reviewed before publication to ensure that the final, published version is comprehensive and accessible. The reviewers who approved the final version are listed with their names and affiliations.

\section{The reviewers who approved this article are:}

\section{Version 1}

\section{Shih-Ann Chen}

${ }_{1}^{1}$ Division of Cardiology, Department of Medicine, Taipei Veterans General Hospital, Taipei, Taiwan

2 Institute of Clinical Medicine and Cardiovascular Research Center, National Yang-Ming University, Taipei, Taiwan Competing Interests: No competing interests were disclosed.

\section{Andrea Natale}

Texas Cardiac Arrhythmia Institute, St. David's Medical Center, Austin, USA

Competing Interests: No competing interests were disclosed.

The benefits of publishing with F1000Research:

- Your article is published within days, with no editorial bias

- You can publish traditional articles, null/negative results, case reports, data notes and more

- The peer review process is transparent and collaborative

- Your article is indexed in PubMed after passing peer review

- Dedicated customer support at every stage

For pre-submission enquiries, contact research@f1000.com 